\title{
Considerations on a Brachauchenius skeleton (Pliosauroidea) from the lower Paja Formation (late Barremian) of Villa de Leyva area (Colombia)
}

\author{
Oliver Hampe* \\ Museum für Naturkunde der Humboldt-Universität zu Berlin, Institut für Paläontologie, Invalidenstraße 43, D-10115 Berlin, \\ Germany
}

Received 2 February 2004, accepted 17 May 2005

Published online 02. 11.2005

With 10 figures

Key words: Brachaucheniidae, Colombia, pliosaur distribution.

\begin{abstract}
A nearly complete pliosaurid skeleton has been discovered in the Barremian deposits (Formación Paja) of Villa de Leyva in early 2004. The new find belongs to the genus Brachauchenius and consists of the cranium with a slightly damaged and partially concretionally covered occipital region and a neck with 13 cervical vertebrae. The trunk, both forelimbs and the left hindlimb are preserved. The posterior part of the pelvic girdle and the caudal vertebrae are lacking. The Colombian Brachauchenius represents the first re-occurrence of the non-rhomaleosaurid pliosaurs after a Berriasian-Hauterivian hiatus.
\end{abstract}

Schlüsselworte: Brachaucheniidae, Kolumbien, Verbreitung der Pliosaurier.

\section{Zusammenfassung}

Anfang 2004 wurde das nahezu vollständige Skelett eines Pliosauriers in den Ablagerungen des Barremium (Formación Paja) von Villa de Leyva entdeckt und freigelegt. Der Neufund ist der Gattung Brachauchenius zuzuordnen. Überliefert sind das Cranium mit leicht beschädigter und teilweise konkretionär überdeckter Occipitalregion und eine Halswirbelsäule bestehend aus 13 Wirbeln. Das Rumpfskelett, beide Vorderextremitäten sowie die linke Hinterextremität sind erhalten. Der hintere Abschnitt des Beckengürtels und der Schwanzbereich fehlen. Der kolumbianische Brachauchenius stellt das erste Wiedererscheinen der nicht-rhomaleosauriden Pliosaurier nach dem Berriasium-Hauterivium Hiatus dar.

Palabras claves: Brachaucheniidae, Colombia, distribución de pliosaurios.

\section{Resumen}

Un esqueleto de pliosaurio, casi completo, fué descubierto en depósitos barremianos (Formación Paja) de Villa de Leyva, a comienzos del año 2004. El nuevo hallazgo consiste de un cráneo que tiene la región occipital parcialmente dañada e incompletamente incluida en una concreción y el cuello representado por 13 vértebras cervicales. El tronco, ambos miembros anteriores y sólo un miembro posterior están preservados. La parte posterior de la aleta pélvica y las vértebras caudales no están preservadas. El nuevo especimen fósil se incluye en el género Brachauchenius. El Brachauchenius colombiano representa la primera reaparición de pliosaurios no rhomaleosaurid despues del intervalo Berriasiano-Hauteriviano. 


\section{Introduction}

The skeleton of a small pliosaur was discovered about $4.5 \mathrm{~km}$ west-northwest of Villa de Leyva, Republic of Colombia, in early 2004 (Fig. 1, 2). The age of the specimen can be determined from numerous finds of the ammonite Heinzia sp. which are late Barremian in age (Patarroyo 2000). A subsequent study of the skeleton indicated a close relationship with the North American pliosaur Brachauchenius, an inhabitant of the Late Cretaceous Western Interior Seaway.

Traditionally, the advanced taxa of the monophyletic clade Sauropterygia (a.o. Storrs 1993; Rieppel 1999) are divided into the long-necked plesiosauroids having small heads and the shortnecked pliosauroids generally having a large head, as established by several authors in the past (Tarlo 1960; Persson 1963; Brown 1981).

A number of different opinions concerning plesiosaurid and pliosaurid evolution were published during the last decade of the 20th century. Bakker (1993) postulated the descendancy of long-necked elasmosaurids from short-necked Jurassic pliosaurids, but based that only on the superficial structure of the ventral surface of the braincase and on correlations with extinction events. Carpenter (1997: Fig. 10) suggested a closer relationship between polycotylids and elasmosaurs than between polycotylids and the "classic" pliosaurs. Bardet \& Godefroit (1998) later confirmed Carpenter's suggestion. Druckenmiller (1999) proposed that pliosauroids were paraphyletic in a phylogenetic analysis. O'Keefe (2001) presented a taxonomic revision of the Plesiosauria proposing a breakup of the formerly supposed monophyletic pliosauroids based on an cladistic analysis. In a later paper, O'Keefe (2002) discussed a pliosauromorph body shape that he proposes evolved three times. One group, the polycotylids (Trinacromerum, Dolichorhynchops), represent a sister clade to the Cimoliasauridae which are closely related to the cryptocleidids (and descended from a taxonomic group named Tricleidia). O'Keefe (2002: Fig. 2) then considered the Pliosauridae, containing taxa such as Peloneustes and Liopleurodon to belong to a second group, while a third group is composed of the taxa Simolestes and Leptocleidus within the Rhomaleosauridae. Rhomaleosauridae and Pliosauridae are sister groups in O'Keefe's analyses $(2001,2002)$ with the Rhaetian/Hettangian Thalassiodracon hawkinsi (Storrs \& Taylor 1996) as their common ancestor.
Pliosaurs were top predators of the Late Jurassic and Early Cretaceous oceans. Evidently they fed on cephalopods as shown by the stomach contents of Pliosaurus brachyspondylus (Tarlo 1959a: Pl. 52, Fig. 2) but also on fish, as demonstrated by a calcified teleost vertebra located between the anterior dorsal vertebrae of the skeleton described in this article (see below). Possible pliosaur bite marks are known from Callovian cryptocleidid propodials (Martill et al. 1994). Thulborn \& Turner (1993: Fig. 4) document an elasmosaur cranium from Queensland pierced by tooth marks that appear to be related in size and arrangement to the dentition of the large Kronosaurus.

\section{Regional vertebrate finds}

Villa de Leyva is not only famous for historical buildings of the Spanish conquerers, but also for the rich abundance of fossils in the Cretaceous deposits surrounding this little town. The locality is situated on the Eastern Cordillera in the Department of Boyacá, approximately $150 \mathrm{~km} \mathrm{NE}$ of the capital Bogotá

During the Cretaceous the Eastern Cordillera including the Río Magdalena Valley formed a basin limited to the west by the arc-trench-system of the Andes and the Guayana Craton in the east (see Mann et al. 1994). About 7000 to $9000 \mathrm{~m}$ of Cretaceous sediments were deposited in this basin. Biostratigraphical investigations show that the sediments range in age from the Hauterivian to the Santonian (Etayo Serna 1968). Early Cretaceous deposits predominate. Ammonites are extremely common in the Barremian and Aptian. The Eastern Cordillera/Río Magdalena Valley area is interpreted as a marginal marine deposit (Forero \& Sarmiento 1985, Mann et al. 1994).

Vertebrate remains were known since the discovery of elasmosaurid remains between 1945 and 1948. Since Bonaparte (1978), who recognized the elasmosaurid Alzadasaurus colombiensis as the only known fossil marine reptile of Colombia, the number of vertebrate discoveries has increased during recent decades, especially in Villa de Leyva. Welles (1962) thoroughly described Alzadasaurus colombiensis from the lower Aptian of Loma La Catalina (Fig. 1). Today, this species is known under the genus Callawayasaurus, following a revision of North American Cretaceous elasmosaurs by Carpenter (1999: 172). Further remains of Callawayasaurus colombiensis, including a skull from Loma La Cabrera, were reported by Goñi \& Gasparini (1983).

In 1977 a local farmer discovered a giant Kronosaurus skeleton west of Villa de Leyva near the road to Santa Sofía (Acosta et al. 1979). This $7.04 \mathrm{~m}$ long specimen (lacking the caudal region) was later described in detail and determined by Hampe (1992) as a new species: Kronosaurus boyacensis.

Gómez (2001) described, in her Master's thesis, a partial skeleton with superbly preserved skull from the Barremian of Loma Catalina (Fig. 2) as Kronosaurus n. sp., aff. K. boyacensis. A publication on this specimen in a scientific journal is in preparation. Additional Kronosaurus material has also been recovered from some other places of the Villa de Leyva region. The new brachaucheniid was discovered in early 2004 (Fig. 2) and excavated by the "Fundacion Colombiana de Geobiologia" under María E. Páramo from the Instituto Colombiano de Geologá y Minerá (INGEOMINAS), Bogotá. Dr. Páramo will provide with her research group a comprehensive description of this new pliosaur in the near future.

Turtles from the Villa de Leyva region are only known from isolated remains, principally mandibular and skull frag- 


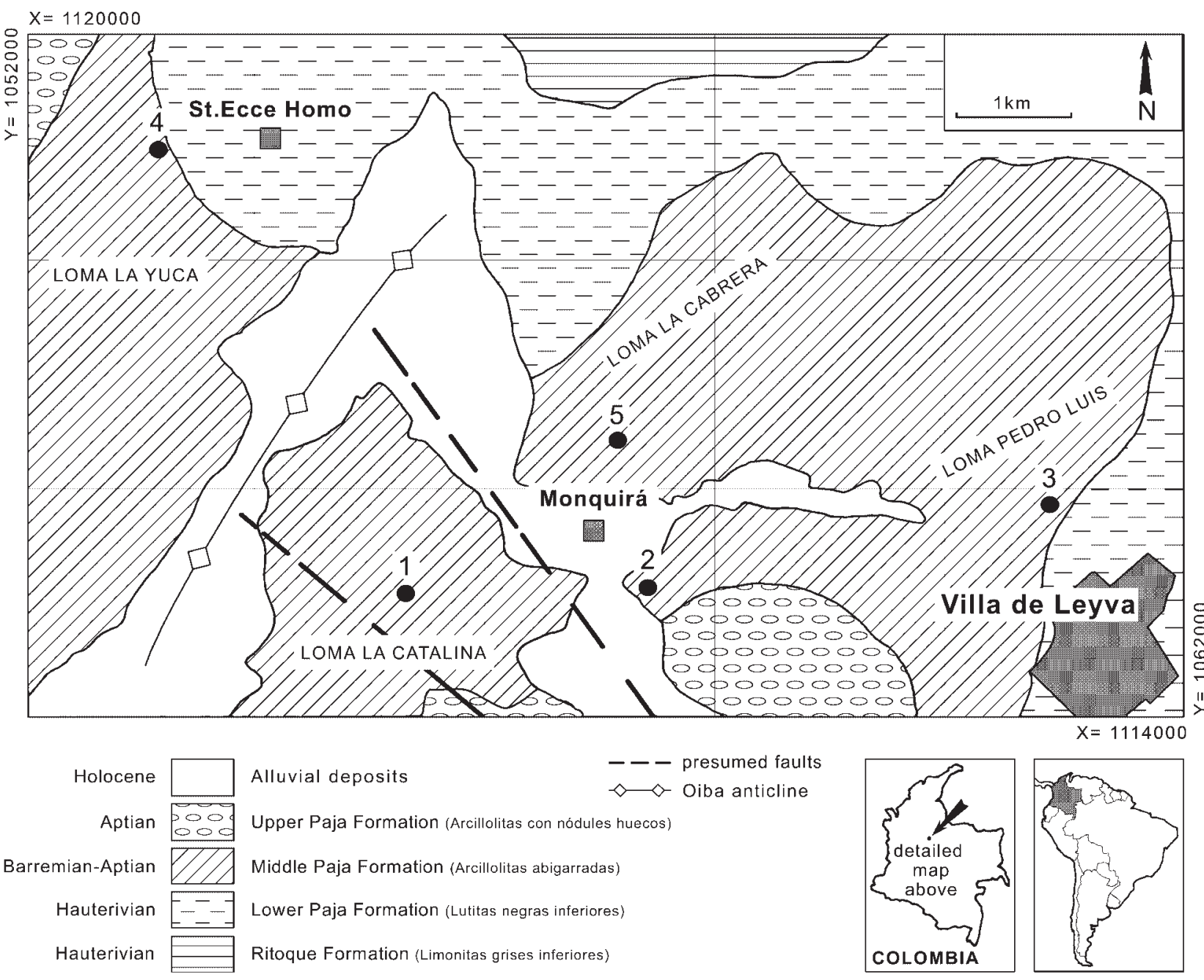

Fig. 1. Geological map of the Villa de Leyva area showing the localities of important marine reptile discoveries: 1 Callawayasaurus colombiensis (Welles 1962); 2 - Kronosaurus boyacensis Hampe 1992; 3 - Platypterygius sachicarum Páramo 1997; 4 - Kronosaurus n. sp., aff. K. boyacensis, Gómez 2001; 5 - Brachauchenius sp. VL.

ments (de la Fuente \& Goñi 1983). Páramo (1997) described the well preserved skull of the ophthalmosaurid Platypterygius sachicarum from Loma Pedro Luis about $1.5 \mathrm{~km} \mathrm{~N}$ of Villa de Leyva (early Aptian, Fig. 1) and there are several undescribed ichthyosaur specimens consisting of partial skulls and vertebral columns (pers. observ.) from this area.

Besides the reptiles, other vertebrates of this BarremianAptian sea are represented by actinoperygian fish, mainly teleosts. Numerous nodules from the Paja Formation contain various fish remains, often consisting of complete skeletons. The aspidorhynchid Vinctifer, a halecomorph, which is well known from the Albian Santana Formation of Brazil (Brito 1997) and from the late Albian deposits of the Tlayúa Quarries in Mexico (Applegate 1996), is also documented from the Lower Cretaceous of the Villa de Leyva region (Schultze \& Stöhr 1996). Complete bodies and isolated heads of large representatives of the Ichthyodectidae, known from the Cretaceous Western Interior Seaway (Nicholls \& Russell 1990) are also known (pers. observ.). Notwithstanding, further investigation is needed to establish whether these spectacular animals belong to the North American forms Xiphactinus or Ichthyodectes, or whether there are affinities to a genus from the southern hemisphere, such as Cooyoo, found in Albian deposits of Queensland, Australia (Lees \& Bartholomai 1987) precisely in that area where the type and additional material of Kronosaurus queenslandicus was found (Longman 1924; Romer \& Lewis 1959; Molnar 1991).

\section{Systematic palaeontology}

Order Sauropterygia Owen, 1860

Infraorder Plesiosauria de Blainville, 1835

Superfamily Pliosauroidea Welles, 1943

Family Brachaucheniidae Williston, 1925

\section{Brachauchenius Williston, 1903}

Brachauchenius sp. VL (abbreviation for Villa de Leyva)

Figs 2-5, 7, 8

Locality: Loma La Cabrera, WNW Villa de Leyva, Boyacá, Colombia; UTM coordinates N 1057140, E 1116398, elevation $2150 \mathrm{~m}$ (navigational accuracy to $9 \mathrm{~m}$ ).

Age: Formación Paja (Arcillolitas abigarradas), late Barremian, Early Cretaceous.

Material: A nearly complete skeleton consisting of a cranium with a slightly damaged occipital region, trunk, both forelimbs and the left hindlimb. Parts of the pelvic girdle (ischia) and the caudals are not preserved. The overall length of the skeleton is $3.83 \mathrm{~m}$ between tip of the rostrum and the base of the tail. 
Description: Cranium - The length of the skull is about $1.2 \mathrm{~m}$ (the snout is estimated at $23 \mathrm{~cm}$ in length after reconstruction from the rostral fragments plus $97 \mathrm{~cm}$ for the rest of the skull). The maximum width at the lower jaw rami measures $58.3 \mathrm{~cm}$. Concretions cover, in particular, the parietal and temporal regions (Fig. 3). The occurrence of hard iron-rich concretions is a common phenomenon of fossil vertebrates from the Paja Formation (Hampe 1992). The premaxillae are preserved, but the rostralmost part is broken. The maxillae are well distinguishable, but the fronto-parietal area between the orbits is less well preserved (Fig. 3). The postorbital region is mostly fragmentary.

The anterior part of the rostrum is broken, but pieces of it were recovered so that the entire length of the snout can be estimated with a high reliability (see above). The premaxillae are slender paired bones arranged in parallel with more or less the same width over their entire preserved length. At about the same level as the anterior margin of the orbits the premaxillae meet the frontals in a zig-zag suture (Fig. 3). The frontals have a bean- or kidney-shaped outline in dorsal aspect, elongated antero-posteriorly and form the dorsal margin of the orbits. A small trapezoid prefrontal bone connects the nares and the orbit which is seen best on the left side of the cranium. No lacrimal is present. Nasals are also absent.

The maxillae are long bones that form the lateral walls of the rostrum. They increase in width posteriorly. The maxilla forms the anterior and lower margin of the orbit. The maxillar descending process, which decreases in dorso-ventral height, meets the jugal at about the half of the lower margin of the orbit. On the right side the remain of a jugal is visible (Fig. 3). The nares are relatively large, longitudinally oval and nearly completely surrounded by the maxillae, only a small posterior part of the margin is formed by the prefrontal (naris length, right $=9.6 \mathrm{~cm}$; naris length, left $=9.8 \mathrm{~cm})$.

The orbits measure approximately twice the length of the nares. Behind the left orbit a fragmentary bone slanting into the sediment may be the postorbital.

The posterior sagittal third of the vertex is covered by a concretion (Fig. 3). Some bone, such as the probable epipterygoid visible in the left temporal fenestra, is seen below the concretion. The dorsal portions of the squamosals are abraded or displaced. Only the thick and robust posterior descending portions remain in place. A fragment of the opisthoticum is visible on the right side of the skull, medial to the squamosal. Parts of the massive quadrates appear ventral to the squamosal remains on the occipital aspect of the cranium. Unfortunately, the ventral side of the head is not exposed yet. The lateral margin of the quadratal ramus of the pterygoid is identifiable in the right temporal fenestra.

Mandible - The mandibular rami are quite well preserved. The anterior portion of the dentary occupies a little less than two thirds of the

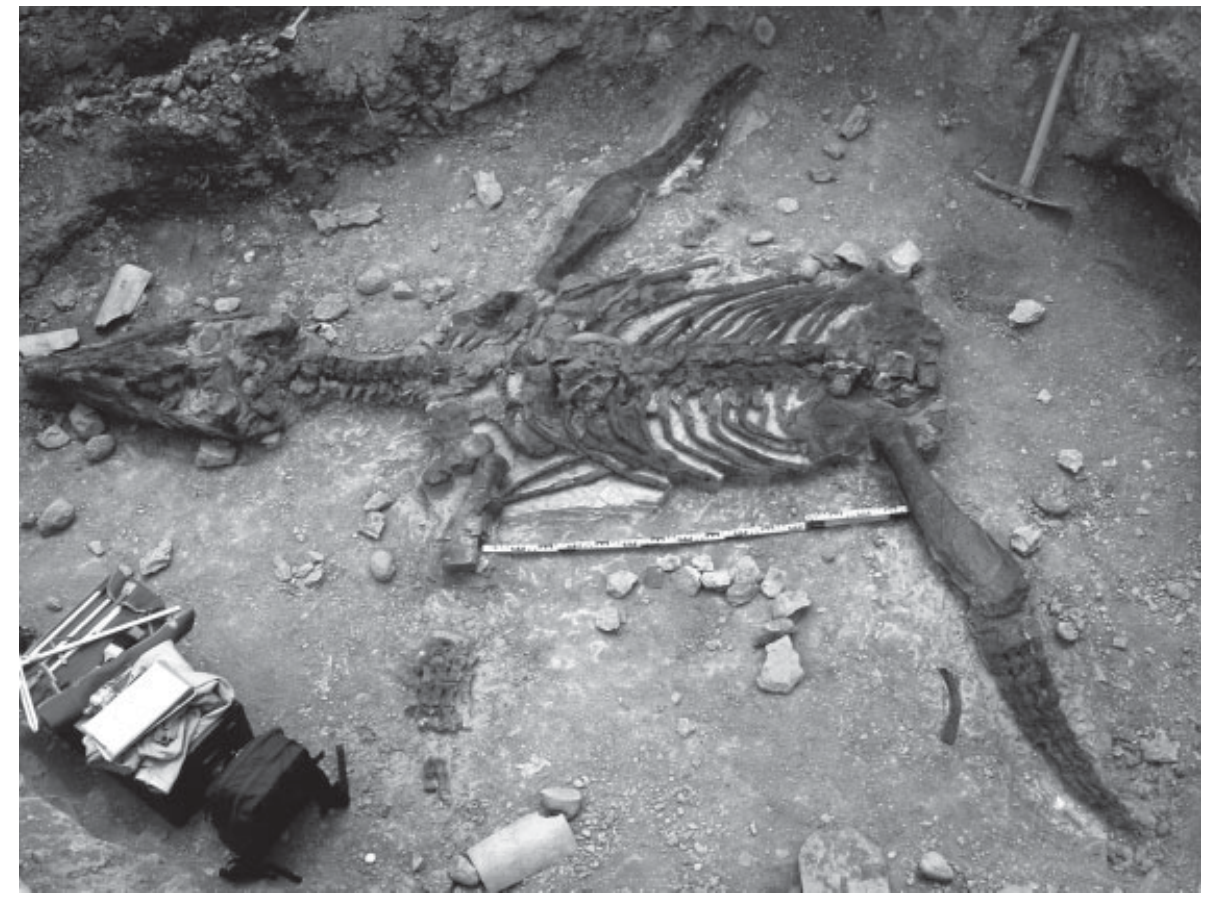

Fig. 2. Uncovered skeleton of Brachauchenius sp. VL from the late Barremian Formación Paja of Loma La Cabrera, Villa de Leyva area, in dorsal view. The far posterior part (ischia, tail) and the right hind limb are not preserved. 

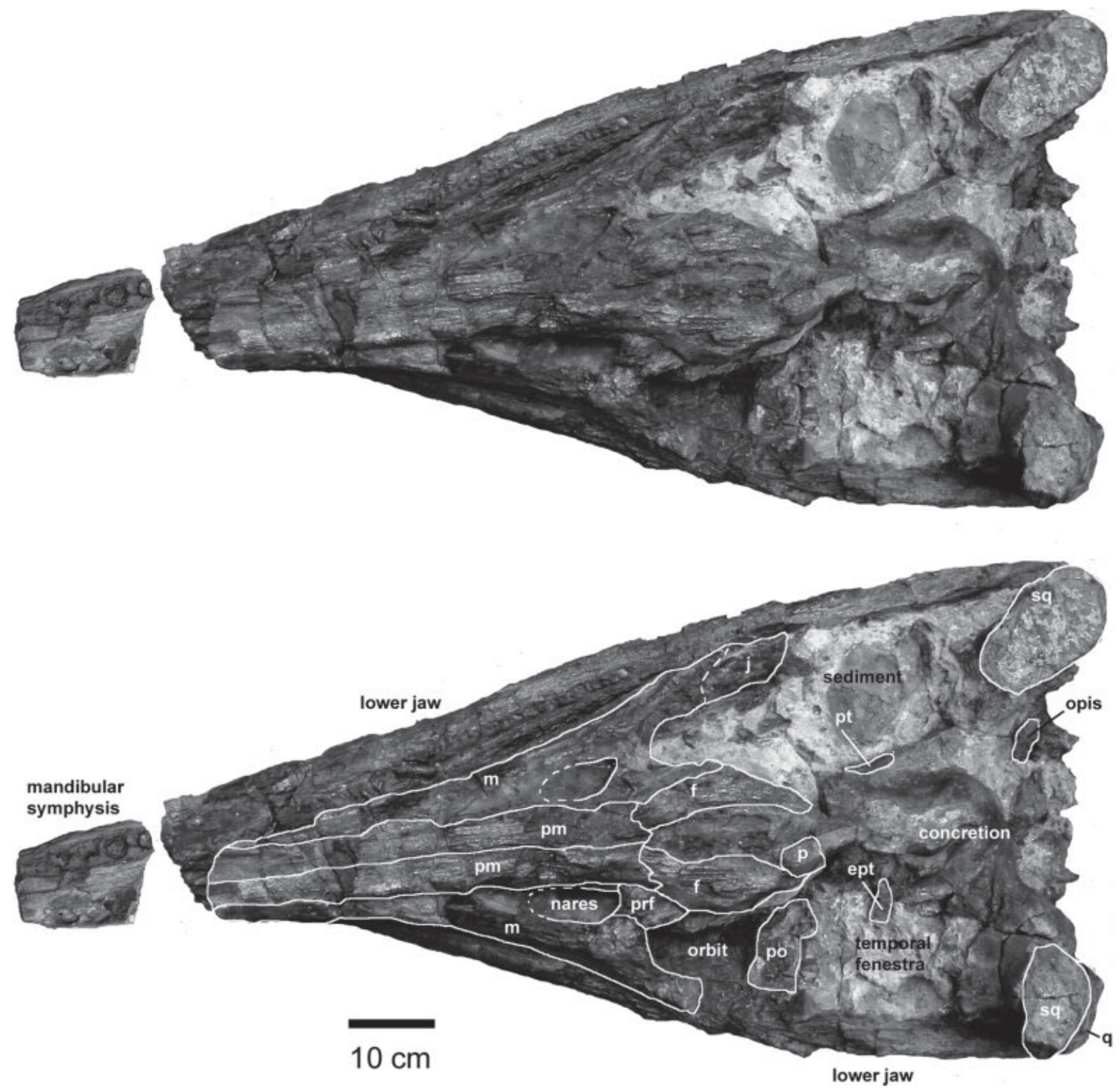

Fig. 3. Brachauchenius sp. VL: skull in dorsal view with highlighted bone sutures (below); non-stereoscopic images. Abbreviations: a - angular; art - articular; d - dentary; ept - epipterygoid; f - frontal; j - jugal; m - maxilla; opis - opithoticum; $\mathbf{p}$ parietal; pm - premaxilla; po - postorbital; prf - prefrontal; pt - pterygoid; $\mathbf{q}$ - quadrate; sa - surangular; sq - squamosal.

entire length of the ramus (Fig. 4). The angular and surangular are determinable. The ventrally positioned angular has a gently curved dorsal margin. The surangular is shorter and does not reach the posterior end of the ramus, as usual in pliosaurs, ending anteriorly in a zig-zag-shaped suture with the dentary. The angular forms the retroarticular process and meets the dentary further anteriorly than the surangular (Fig. 4). A small articular bone seems to be exposed at the posterior end of the jaws. Remnants of a possible coronoid process are also visible dorsal to the surangular-dentary suture on the dorsal margin of the right ramus.
Teeth - The dentition of Brachauchenius sp. VL is unisodont. The $13.6 \mathrm{~cm}$ long fragment of the mandibular symphysis (Fig. 3) bears relatively large teeth. The diameter of the best preserved most anterior socket of the left side is $25 \mathrm{~mm}$ long and $18 \mathrm{~mm}$ wide and the posterior socket of the right side is $24 \mathrm{~mm}$ long and $22 \mathrm{~mm}$ wide. Brachauchenius sp. VL has about 30 pairs (or a little less than 30) of teeth in the lower jaw. Generally, the lateral and distal teeth of the dentition are smaller, and teeth of the lower jaw seem to be a little larger than those of the upper jaw. Due to the poor preservation of the enamel nothing can be said about the ornamentation of the tooth crowns. 


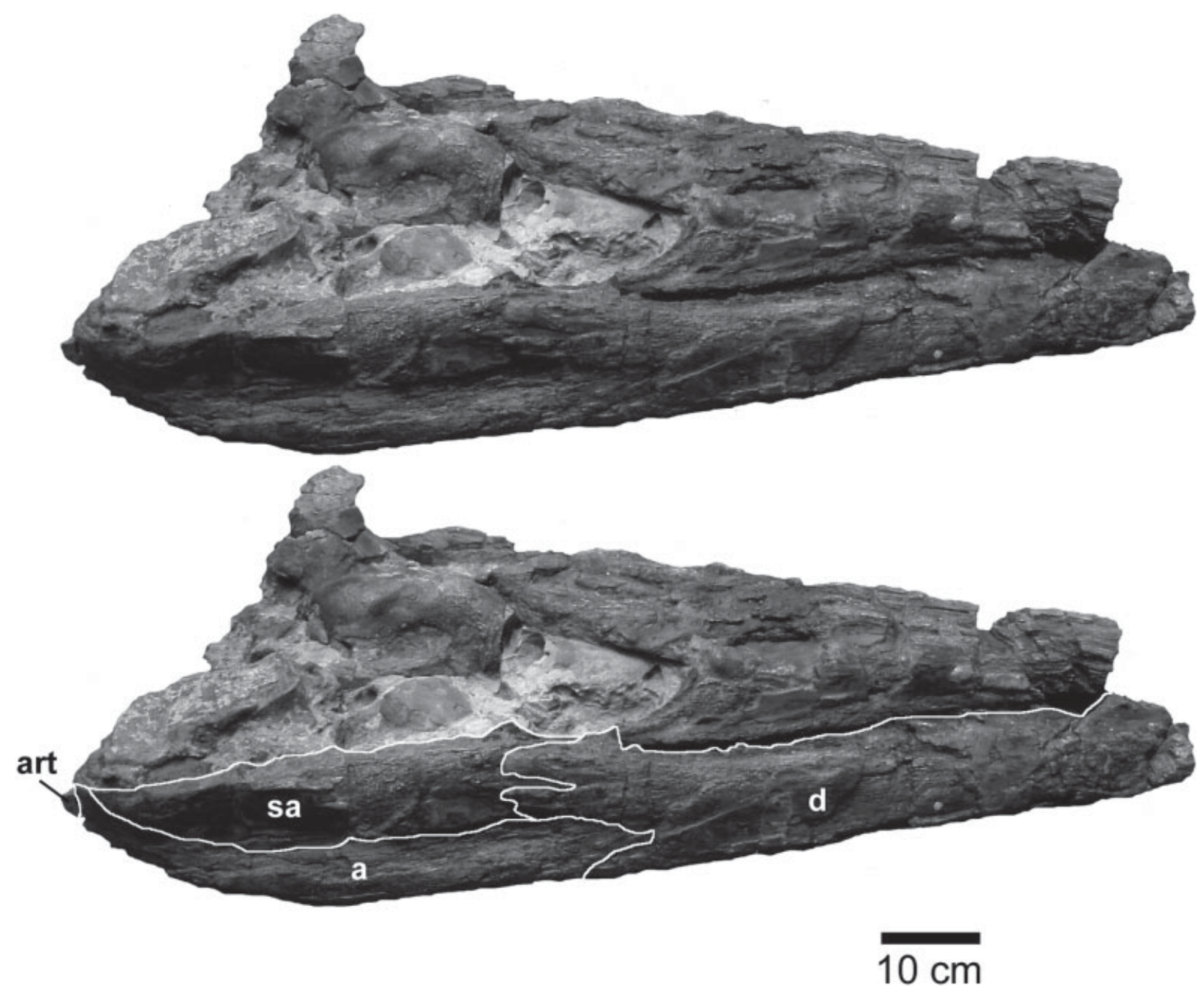

Fig. 4. Brachauchenius sp. VL: skull in right view with highlighted bone sutures of the lower jaw. Abbreviations, see Fig. 3.

Axial skeleton - The skeleton consists of 13 cervical, about 20 dorsal, and probably a few sacral vertebrae. Caudal vertebrae could not clearly be determined. Of the cervical vertebrae, only the centra are preserved. The atlas and axis are covered with concretional material. All cervicals are typical for a pliosaurid, being broader than long. Length and width show a slight increase in posterior direction (see measurements below). In anterior and posterior views, the rounded centra are slightly constricted laterally. The ventral aspect has an anteriorly projecting sagittal margin. A ventral keel is not developed at the cervicals. The cervical centra have single rib facets that cover nearly the entire lateral surface and show a somewhat rectangular to trapezoidal outline (see Fig. 5). The rib facets decrease in size posteriorly.

The measurements (in $\mathrm{mm}$ ) of the cervical centra are as follows (approximate measurements in parentheses):

$\begin{array}{lcc}\text { atlas } & \begin{array}{c}\text { Length } \\ (43)\end{array} & \begin{array}{c}\text { Width } \\ 99\end{array} \\ \text { axis } & 36 & (106) \\ 3^{\text {rd }} \text { C.v. } & 33 & (107) \\ 4^{\text {th }} \text { C.v. } & 46 & 83 \\ 5^{\text {th }} \text { C.v. } & 36 & 84 \\ 6^{\text {th }} \text { C.v. } & 39 & 94 \\ 7^{\text {th }} \text { C.v. } & 38 & (96) \\ 8^{\text {th }} \text { C.v. } & 37 & 94 \\ 9^{\text {th }} \text { C.v. } & (50) & 103 \\ 10^{\text {th }} \text { C.v. } & 43 & 104 \\ 11^{\text {th }} \text { C.v. } & (44) & 107 \\ 1^{\text {th }} \text { C.v. } & 49 & 117 \\ 13^{\text {th }} \text { C.v. } & 56 & 117\end{array}$

The dorsal vertebrae are distinctly longer than the cervicals. The anteriormost dorsals in the shoulder girdle region are covered by concretions. The preserved neural spines of the dorsal vertebrae average approximately $100 \mathrm{~mm}$ in height. They are all dislocated from the centra 


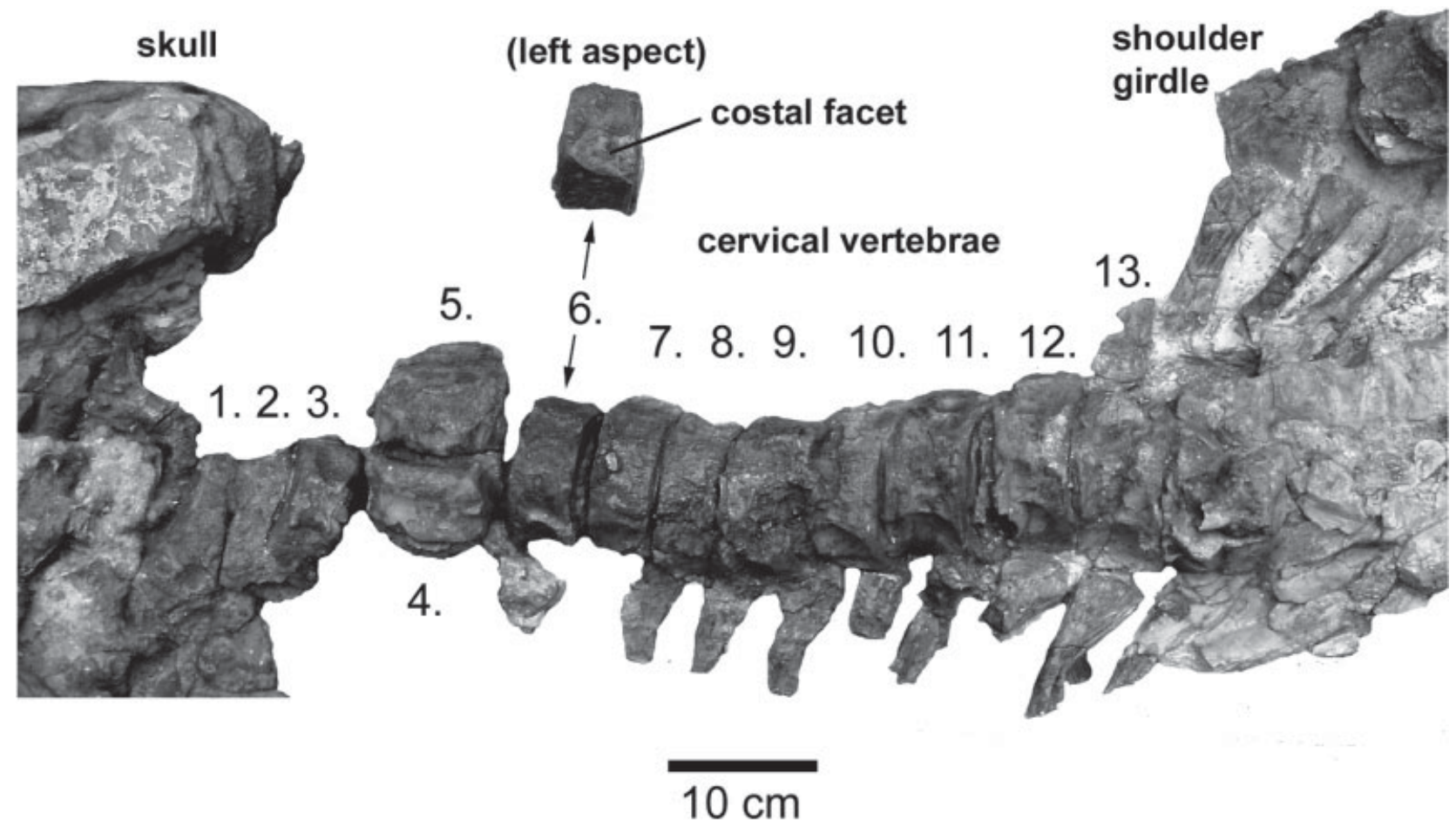

Fig. 5. Brachauchenius sp. VL: vertebral column of the neck in dorsal view.

and lie on the right side of the body up to the $12^{\text {th }}$ dorsal - behind the $12^{\text {th }}$ they lie on the left side (Fig. 2). There is no increase in thickness at the distal ends of the neural processes. Zygapophyses are absent on the posterior dorsal vertebrae. The caudal-most preserved vertebrae are possibly sacrals. They seem to be nearly as long as wide and separate but are covered also with concretions.

The cervical ribs have a broad base and narrow towards their lateral end (Fig. 5). The trunk contains 14 to 15 preserved pairs of ribs. The ribs are slender and slightly less than $30 \mathrm{~mm}$ in diameter.

A teleost vertebra was found between the probable $6^{\text {th }}$ and $7^{\text {th }}$ dorsal vertebrae (Fig. 6) approximately where the gullet was originally.

Appendicular skeleton - The triradiate scapulae of which the ventral plate has the broadest diameter are fragmentary (Fig. 7). The glenoid ramus is distally abraded so that the usual triangular shape of the end, which contains the anterior half of the glenoid cavity, is not visible. The dorsal process is more or less straight, not caudally curved. All rami diverge from each other at an obtuse angle.

The coracoids are covered by the rib cage.

The measurements are as follows:

Scapula, left:

diameter of glenoid ramus $9.1 \mathrm{~cm}$

diameter of dorsal process $8.9 \mathrm{~cm}$

diameter of ventral plate $(16 \mathrm{~cm})$
Coracoid, left:

length approximately $52 \mathrm{~cm}$

The limbs are exceptionally long. The right anterior extremity is almost completely preserved, and only a few distal phalanges are pos-

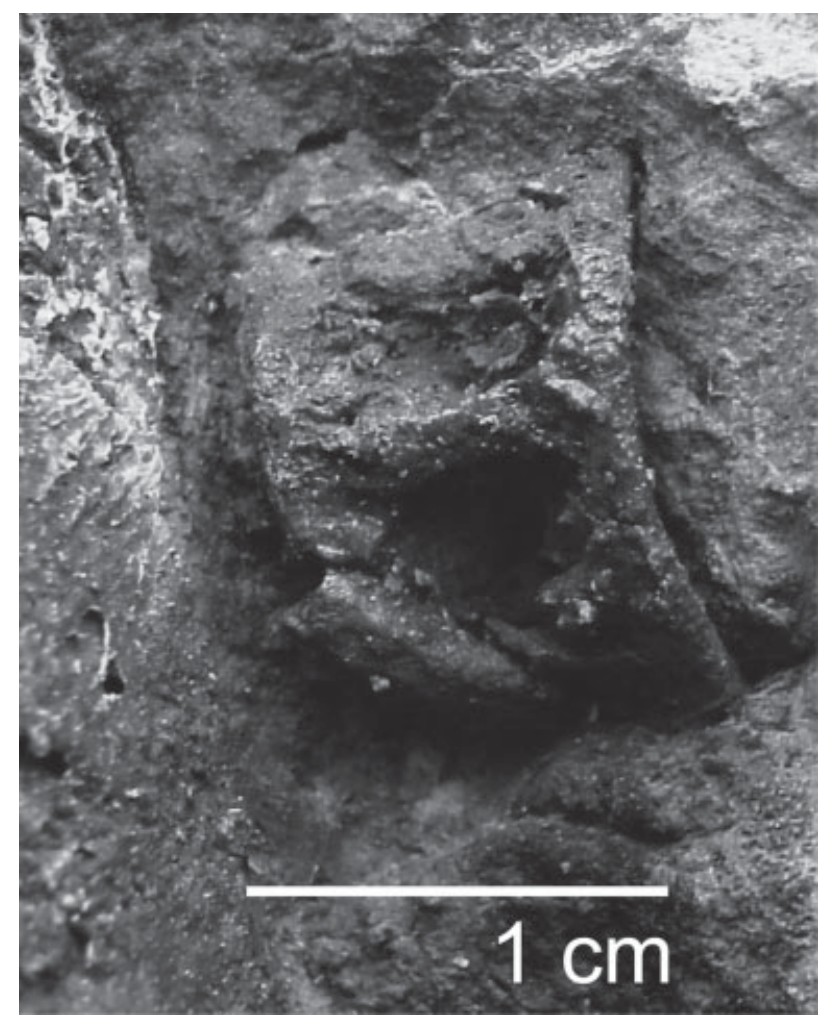

Fig. 6. Teleost fish vertebra, preserved between the anterior dorsal vertebrae of the Brachauchenius sp. VL skeleton. 
sibly missing. The right humerus is complete (Fig. 8), whereas the left lacks the distal part. The humeri are bottle-shaped with a distinct collum distal to the humeral head. The diaphysis decreases moderately in width towards the proximal end. The distal end of the humeri is gently rounded. Epicondylar processes are not developed.

The epipodial elements are difficult to describe because of their poor preservation (Fig. 8). The short radius and ulna are followed distally by two carpal elements, probably the intermedium and ulnare, which in turn are succeeded by two distals in the right anterior limb. Beyond the elongated metacarpals the II. digit is preserved, with 11 phalanges, the III. with 10

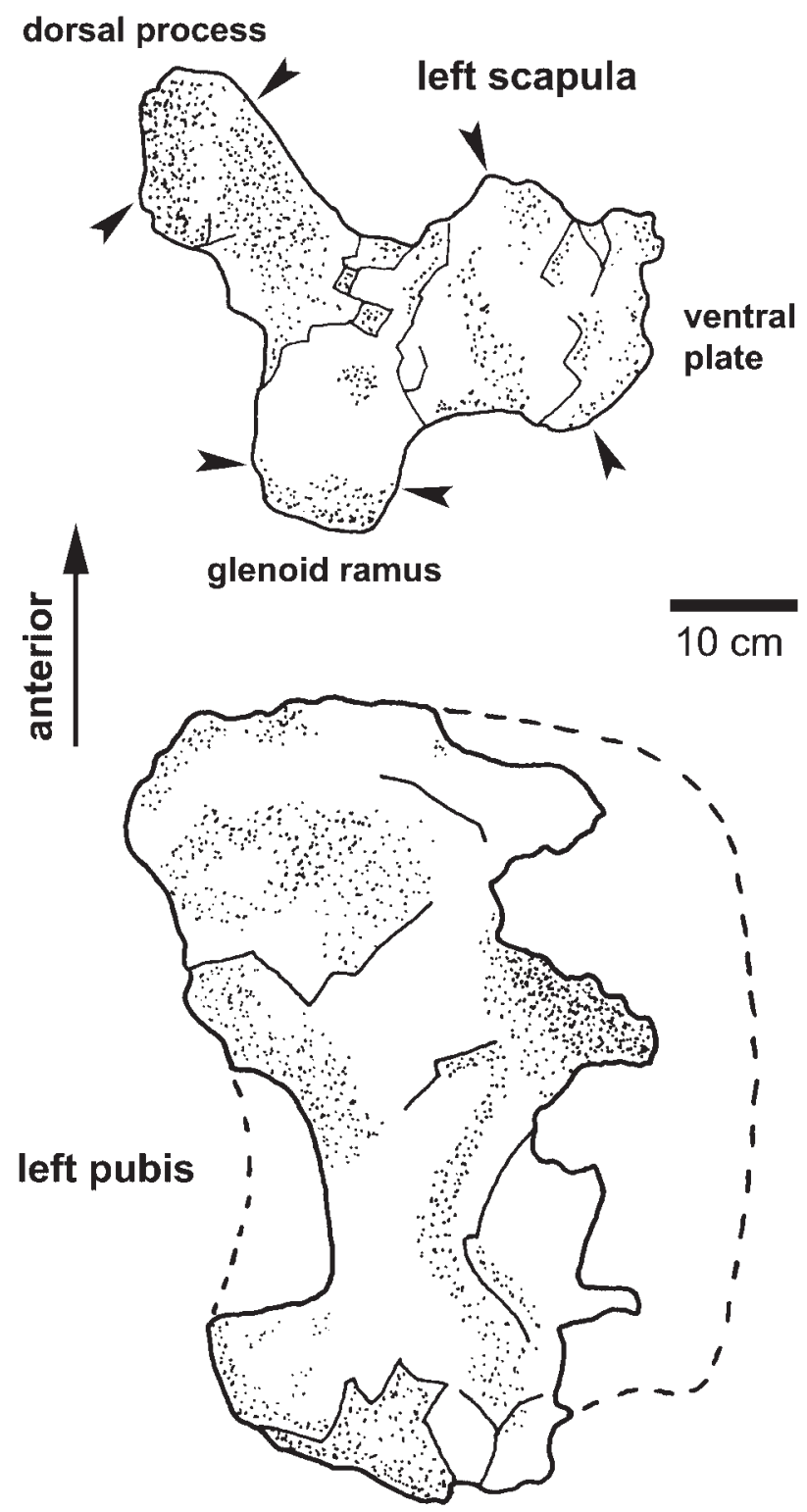

Fig. 7. Brachauchenius sp. VL: left scapula and pubis, both in dorsal view. Arrows mark the measurements of the scapular processes (see text)

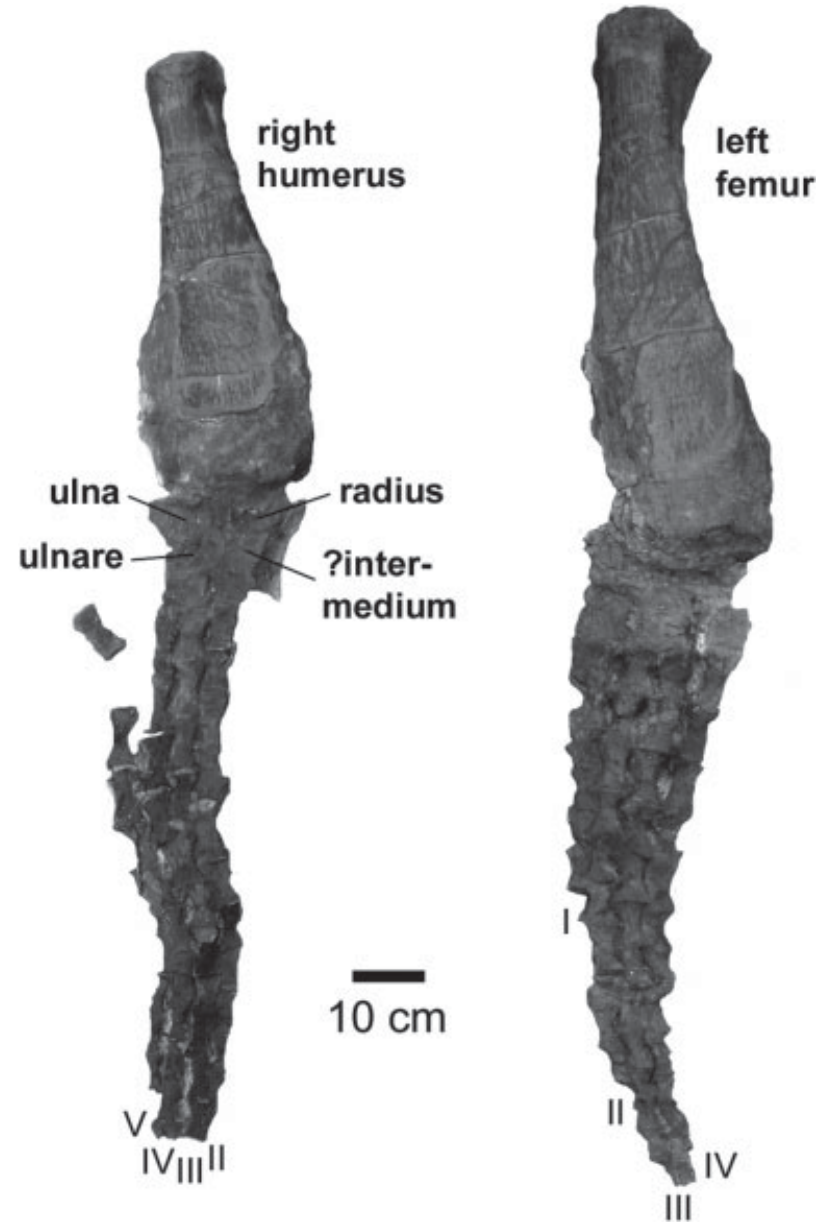

Fig. 8. Brachauchenius sp. VL: right forelimb and left hindlimb in lateral views.

phalanges, the IV. with 10 phalanges, and the V. also with 10 phalanges, all of more or less hourglass form.

The measurements are as follows:

Humerus, right:

length $66.6 \mathrm{~cm}$

maximum distal width $(22 \mathrm{~cm})$

minimum width of the diaphysis $9.6 \mathrm{~cm}$

Like the pectoral girdle, the pelvic elements are only partially preserved. The maximum length of the left pubis can be established (Fig. 7) at $60.4 \mathrm{~cm}$. The anterior edge of the right pubis is damaged. The ischia and ilia are not preserved. The left hindlimb is in good condition with the exception of the abraded distal anterior margin (Fig. 8). A fibular epicondyle is not deteminable. The femur is extremely slender and the proportions show an even more slender appearance than that of the humerus. There is only a shallow collum distal to the femoral head. The epipodials and following tarsals are covered both by the distal end of the 
femur and sediment (Fig. 8). It is estimated on the basis of visible elements that the I. digit has about 5 phalanges, the II. has 7-8 phalanges, the III. about 12 phalanges, and the IV. has 13 phalanges preserved below the metatarsals. The ratio between the length of the trunk (from the end of the cervical column to the last preserved sacral) and the left hind limb is nearly $1: 1$. Similar proportions in a pliosauromorph bauplan are known only from the Callovian/Oxfordian Peloneustes philarchus (e.g. Andrews 1910: Pl. XII) and the Campanian polycotylid Trinacromerum bonneri, described by Adams (1997).

The measurements are as follows:

Femur, left:

length $82 \mathrm{~cm}$

maximum distal width $(24 \mathrm{~cm})$

minimum width of the diaphysis $11.3 \mathrm{~cm}$

\section{Discussion}

The following discussion reports several mosaic character patterns for the new Colombian find as has been demonstrated already for the earliest Cenomanian form Plesiopleurodon wellesi from Wyoming (see diagnosis in Carpenter 1996: 263f).

Beginning with the cranial rostrum, the snout of Brachauchenius sp. VL is not scoop-like as in rhomaleosaurids, but tapers gradually (based on the preserved region of the anteriorly tapering mandibular symphysis) as in Liopleurodon ferox from the Callovian of Peterborough, England, Brachauchenius lucasi from the Cenomanian/Turonian of Kansas, Plesiopleurodon wellesi (Fig. 9), and some Pliosaurus species.

The premaxillae do not participate in the margins of the nares in Brachauchenius sp. VL, which is also the case in several other pliosaurs. The maxillae have a thin, posteriorly directed spine-like process that separates the nares from the premaxilla in the new Colombian specimen. The separation of the nares from the premaxillae

Fig. 9. Skull proportions of pliosauroids. The relative positions of the nasal openings and orbits are nearly similar between both Brachauchenius forms, but also to Peloneustes. Dorsal aspect of Kronosaurus queenslandicus after Molnar (1991), Kronosaurus boyacensis after Hampe (1992), Brachauchenius lucasi after Carpenter (1996), Brachauchenius sp. VL (this article), Plesiopleurodon wellesi after Carpenter (1996), Peloneustes philarchus after O'Keefe (2001), Liopleurodon ferox after Andrews (1913). Crania redrawn to the same scale.

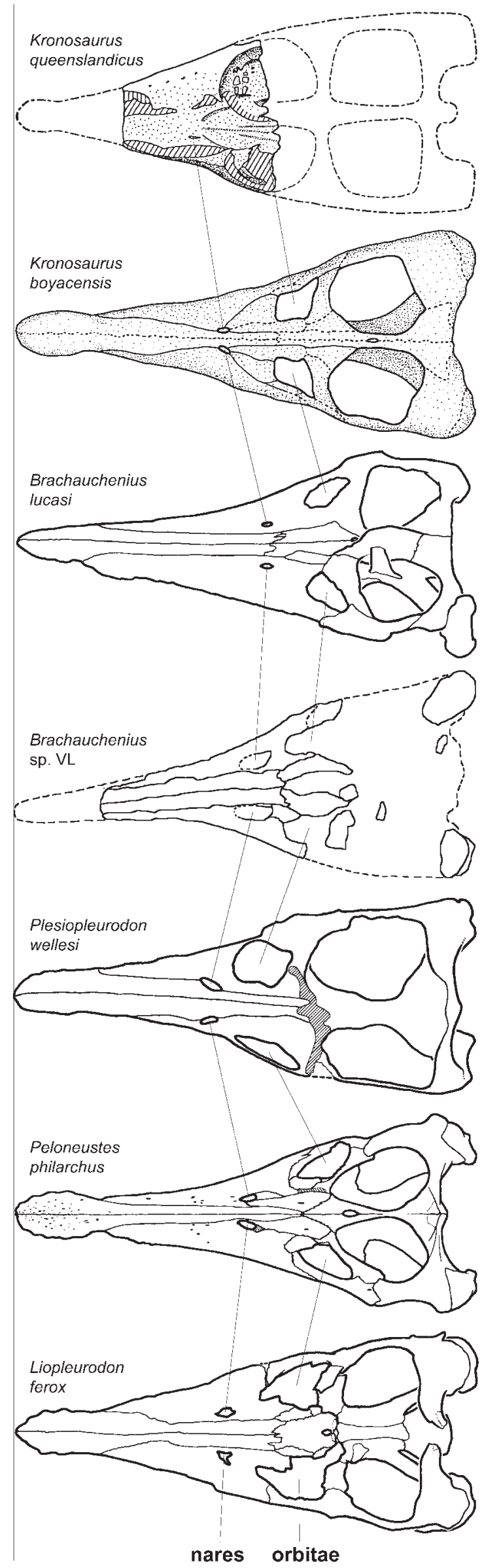


is a key character of the Pliosauridae as defined by O'Keefe (2001) and is seen in Liopleurodon ferox (a.o., Andrews 1897: Pl. XII) and Peloneustes philarchus (a.o., Andrews 1913: Pl. IV) from the Callovian of Peterborough, and the Cretaceous forms Kronosaurus queenslandicus from the Albian of Queensland and Brachauchenius lucasi from the United States (Williston 1907: Pl. XXXVII, Carpenter 1996: Fig. 1). There is a premaxilla-nares contact in Pliosaurus brachyspondylus (Taylor \& Cruickshank 1993: Fig. 4), in Plesiopleurodon wellesi (Carpenter 1996: Fig. 2C), and probably in Kronosaurus boyacensis from the Aptian of the Villa de Leyva area (Hampe 1992: Fig. 2) in contradiction of O'Keefe's diagnosis. The leptocleidids, according to the cladistic analysis by O'Keefe are closely related to the Jurassic Rhomaleosaurus and show a contribution of the premaxillae to the nares. Liopleurodon rossicus from the Kimmeridgian/ Tithonian of the Moscow Basin is the only pliosauroid known so far that exhibits external nares of a large diameter comparable to the new Colombian Brachauchenius (Novozhilov 1948: Fig. 1A). The relative position of the nares and the orbits is quite similar between Brachauchenius lucasi and the Colombian individual, but also comparable with that of Peloneustes philarchus (Fig. 9).

The skull roof of the North American Brachauchenius lucasi shows a regular sequence of the median paired bones with premaxillae followed by frontals and parietals (Carpenter 1996). In the new Colombian Brachauchenius, the frontals are medially not in contact, a character similar to other pliosaurids such as Liopleurodon rossicus (Novozhilov 1948: Fig. 1A), Liopleurodon pachydeirus from the Callovian of Peterborough (Linder 1913: Fig. 24), Pliosaurus brachyspondylus (Taylor \& Cruickshank 1993: Fig. 4), and Kronosaurus boyacensis (Hampe 1992: Fig. 2). They all show a contact between premaxilla and parietal in a straight arrangement. The situation is slightly different in Brachauchenius sp. VL where the frontals have a concave outline medially. Peloneustes philarchus (O'Keefe 2001: Fig. 10) also shows this kind of shape.

The number of teeth in the lower jaw of Brachauchenius sp. VL (about 30 pairs or little less than 30) corresponds well to the number of teeth of about 24-28 in Liopleurodon ferox (Andrews 1897: Pl. XII), and Liopleurodon pachydeirus (28, Linder 1913: 43 as "Pliosaurus ferox", see remarks in Tarlo 1960). Species of the Late Jurassic genus Pliosaurus certainly have over 30 teeth
(Tarlo 1960), and Peloneustes philarchus also has 35-40 teeth (Lydekker 1889: 154; also Linder 1913, Tarlo 1960). Rhomaleosaurids usually have less teeth per ramus $(<25$, e.g., Fraas 1910 for Rhomaleosaurus victor), while Kronosaurus boyacensis has only 24 teeth in the lower jaw (Hampe 1992), and, in addition, the teeth are distinctly larger than in Brachauchenius sp. VL. Brachauchenius lucasi possesses only 21 teeth (Carpenter 1996: 263). The other pliosaur known from the Villa de Leyva area, Kronosaurus n. sp., aff. K. boyacensis, described in the Master's thesis of Gómez (2001), has 21-23 teeth per jaw ramus.

Generally, pliosaurids have a low coronoid process on the mandible as in Brachauchenius lucasi. A little higher coronoid process is developed in Plesiopleurodon wellesi and in the rhomaleosaurid Leptocleidus capensis from the Valanginian/ Hauterivian of South Africa in which the coronoid process reaches double the height of the mandibular ramus (Cruickshank 1997: Fig. 4, 5).

Pliosaurid taxa often have significant ornamentation on the crowns of the teeth (e.g. Tarlo 1960: 183). There is no ornamentation definable on the teeth of the new Colombian Brachauchenius because of poor preservation. Nevertheless, the North American Plesiopleurodon wellesi possesses poorly ornamented teeth (Carpenter 1996).

The number of cervical vertebrae (13) of $\mathrm{Bra}$ chauchenius sp. VL is identical to that of Brachauchenius lucasi (Williston 1907: 486). Both Kronosaurus species, $K$. boyacensis and $K$. queenslandicus have 12 cervical vertebrae (Hampe 1992: 18). Unfortunately, the number of cervicals is not known for Plesiopleurodon wellesi. Other members of the Pliosauridae have a distinctly higher number of cervicals: Liopleurodon pachydeirus has 17 (Tarlo 1960: 167), Liopleurodon ferox about 20 (Andrews 1913: 11f), Peloneustes philarchus 21-22 (Andrews 1913: 35), and Pliosaurus brachyspondylus 19 (Tarlo 1959a: 286). Representatives of the Rhomaleosauridae show also a higher number of cervicals, like Simolestes vorax from the Callovian of Peterborough with about 20 (Andrews 1913: 28), Leptocleidus superstes from the Berriasian of Berwick, England with 19 (Andrews 1922: 288), and Leptocleidus capensis with 21-22 (Cruickshank 1997: 220). Rhomaleosaurid genera with an even longer neck, combined in addition with a comparatively short cranium, include Rhomaleosaurus (e.g. Fraas 1910: Pl. XIII: R. victor; Taylor 1992: Fig. 1: R. zedlandicus; Wyse Jackson 2004: Fig. 8: R. megacephalus), Hauffiosaurus 
(O'Keefe 2001: Fig. 3), and Macroplata (Swinton 1930: Fig. 1).

Brachauchenius sp. VL has single rib facets as is typical for Cretaceous pliosaurs. However, Gómez (2001: 57, Fig. 3.12.) describes Kronosaurus n. sp., aff. $K$. boyacensis, also from the Barremian of the Villa de Leyva region, with a double rib facet on the $3^{\text {rd }}$ cervical centrum.

The scapular proportions of Brachauchenius sp. VL are quite similar to those of Pliosaurus brachyspondylus (Tarlo 1959a: Fig. 2). The ventral plate is very broad whereas the dorsal process includes the most slender part, as is also the case in Pliosaurus brachydeirus (Tarlo 1959b: Fig. 4b). Similarities in scapular proportions are also seen in Peloneustes philarchus (Linder 1913: Fig. 14; v. Huene 1949: Fig. 35), although the dorsal process is more caudally curved in Peloneustes. The reconstructed scapula of Kronosaurus queenslandicus (Romer \& Lewis 1959: Fig. 1) has a distinctly broader glenoid ramus that is only slightly smaller in size than the ventral plate. The dorsal process in Kronosaurus boyacensis is thicker than in other known forms (Hampe 1992: Pls 2, 4). The scapula of Liopleurodon rossicus (Halstead 1971: Fig. 4), however, has a comparable outline to that of Brachauchenius sp. VL. The rhomaleosaurid Simolestes vorax exhibits a narrower ventral plate (Andrews 1913: Fig. 8).

Comparison of the shape of the pelvic girdle is restricted to the pubis because the ischium and ilium are not known from the Colombian Brachauchenius. Compared to Brachauchenius sp. $\mathrm{VL}$, the pubis in Peloneustes philarchus is proportionally longer (Linder 1913: Fig. 15), and nearly of double the length in Kronosaurus queenslandicus (Romer \& Lewis 1959: Fig. 2). The proportions of the pubes of Liopleurodon ferox are similar, but in Liopleurodon the lateral margin of the pubis has a convex projection (Andrews 1913: Fig. 7).

Regarding the limb morphology, Peloneustes philarchus shares with Brachauchenius sp. VL as the only one known so far among the pliosauroids that has extremely long paddles (with an index of about 1:1 for hind limb/trunk).

Gómez (2001) presented a preliminary description of Kronosaurus n. sp., aff. K. boyacensis which will shortly be published in detail (Gómez in prep.). This specimen has also a tapered rostrum and nares positioned within the maxillae. Differences from Brachauchenius sp. VL are displayed in the jugals which extend more anteriorly, the different position of the circumorbital bones, and a higher cranial vertex than in other pliosaurs. Another South American taxon, Maresaurus coccai from the lower Bajocian of Neoquén Basin, Argentina (Gasparini 1997), is supposed to be a rhomaleosaurid and differs in many ways from the Colombian Brachauchenius.

The discussion reveals closest affinities between the here described skeleton from Villa de Leyva and the North American Brachauchenius lucasi, which is known from the skull and the anterior part of the vertebral column (tapered rostrum, relative position of nares and orbits, number of cervical vertebrae). However, there are also some similarities with Peloneustes philarchus from England (position of nares and orbits to each other, scapular proportions, hind limb-trunk ratio).

Carpenter (1996) proposed Plesiopleurodon wellesi, a new taxon, although the specimen upon which it was based was only partially prepared. The still unaccessable ventral side of the cranium of Brachauchenius sp. VL described here prevents the erection of a new species.

The Colombian specimen is the oldest brachaucheniid known so far and represents also the first occurrence of this genus. The specimen indicates a probable origin of the genus in the southern hemisphere (eastern Pacific), outside the Western Interior Seaway of North America, where all discoveries of Brachauchenius were made so far (Kansas, Texas).

\section{Fossil record of pliosaurs}

The pliosaurs are widely distributed during the Jurassic and Cretaceous, both temporally and geographically. These sauropterygians were completely adapted to life in water and are currently grouped into morphotypes (O'Keefe 2002) since their previously suggested monophyly is disproved (see Introduction). Rhomaleosaurids, relatively short-headed forms, are the earliest-occuring pliosauromorphs and known from the Toarcian. The last representatives of the Rhomaleosauridae, seem to become extinct during the Early Cretaceous. Rhomaleosaurids and pliosaurids form a clade, namely the Pliosauroidea.

The Pliosauridae develop through small to medium-sized forms up to gigantic Late Jurassic species of England (Pliosaurus brachyspondylus, Pliosaurus macromerus), Russia [Pliosaurus irgisensis (Novozhilov, 1948) from the Kimmeridgian of Saratov, Liopleurodon rossicus] and North America (the probably invalid taxon Megalneusaurus rex Knight, 1895 based on undiagnostic 


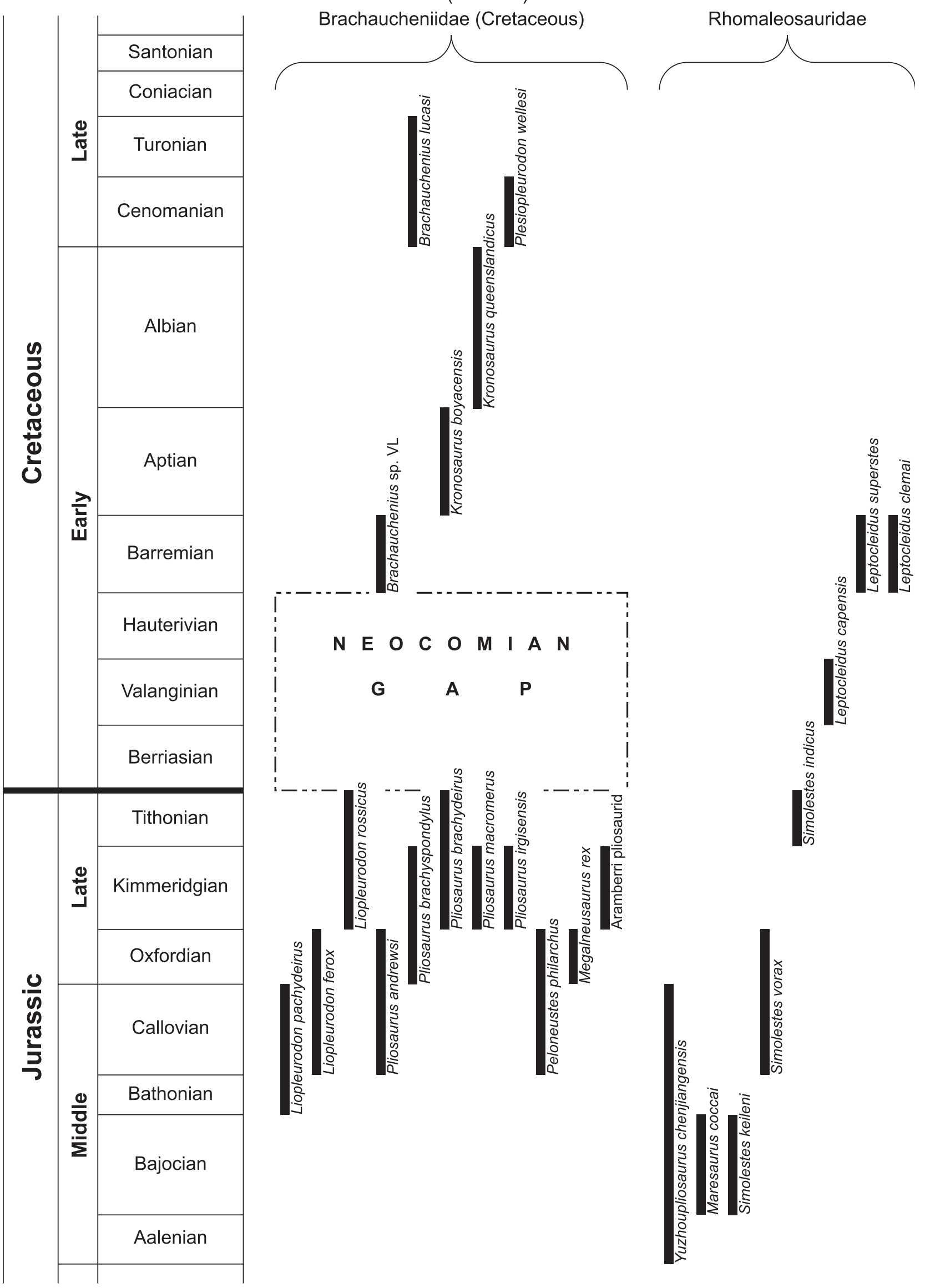


material from Wyoming), and Middle America (an as yet unclassified pliosaurid from Aramberri, Mexico). The Mexican specimen is estimated to have a length of $>15 \mathrm{~m}$, and since there are indications that it represents a not fully grown individual (Buchy et al. 2003: 276), it would therefore be the largest known pliosaur to date.

Then there follows a hiatus with almost no traces of pliosaurids in the Early Cretaceous (Berriasian to Hauterivian, Fig. 10), only the rhomaleosaurid Leptocleidus being known during this time period.

Afterwards, pliosaurids appear again in the fossil record, represented by comparatively small forms in the Barremian (as reported here) developing later into giants, such as Kronosauus queenslandicus in the Albian (length $12.8 \mathrm{~m}$ after Romer \& Lewis 1959). The Cretaceous forms have extremely short necks and are included in their own family, the Brachaucheniidae (revised diagnosis, see Hampe \& Leimkühler 1996).

The question arises, why is there a gap in the fossil record of pliosaurs? Bakker (1993) first proposed a catastrophic event at the J-K boundary for muraenosaurids and cryptocleidids. However, the reason for the postulated event Bakker (1993) left undiscussed. Other long-necked forms, such as the basal elasmosaurid Brancasaurus brancai (Wegner 1914) and a second, recently described taxon are documented from the Berriasian of Westphalia, Germany. Bardet $(1994,1995)$ published on the principles of the evolution and extinction of Mesozoic marine reptiles and confirmed the extinction of the Cryptocleididae at the JurassicCretaceous boundary. Furthermore, she pointed out that the Ichthyosauridae and several families of the Chelonia also disappeared at this boundary.

Nothing has been published previously concerning reasons for extinction of pliosaurs. In any case, no evidence could be established until now for global mass extinctions at or near the Jurassic-Cretaceous boundary. Regional events have only been recognised for molluscs, particularly among bivalves (Hallam \& Wignall 1997: "Tithonian event"). Recently, Flügel \& Kiessling
(2002) demonstrated that, in terms of reef diversity, there was a highly pronounced decline from the Oxfordian to the Valanginian, indicating a long-lasting reef crisis. The maximum production loss appears to take place at the Berriasian-Valanginian boundary. Flügel \& Kiessling (2002: 713 ) identified this boundary as a first-order reef crisis. This crisis apparently caused disturbances in the food web which may have influenced top predators in the ancient oceans. However, further investigations are needed to clarify this hypothesis. It would be important to establish whether there are significant organic and/or sedimentological changes, especially in the units overlying the Kimmeridgian of Southern England (Oxfordshire, Cambridgeshire, Lincolnshire; evidence of genus Pliosaurus), Mexico (Nuevo León; Aramberri pliosaur), and the Volgian of Moscow Basin (Liopleurodon rossicus).

\section{Conclusions}

Brachauchenius sp. VL represents the first evidence of this genus outside the North American Western Interior Seaway. It was found in late Barremian rocks (Formación Paja: Arcillolitas abigarradas) of Loma La Cabrera, WNW Villa de Leyva, Department of Boyacá, Republic of Colombia. The skeleton is also the first record of the non-rhomaleosaurid pliosaurs after the Berriasian-Hauterivian hiatus. However, the reasons for this near absence of these pliosaurs in the fossil record are not yet resolved. A significant reduction in reef production could have disturbed the food web and may have also affected the top predators. The ratio of trunk to hind limb length reveals proportions that are to date only known in Peloneustes philarchus. Remarkably long extremities are interpreted by Adams (1997) as adaptation for advanced swimming speed. Brachauchenius sp. VL provides the first evidence that pliosaurs included fish in their diet. A teleost vertebra was embedded between the anterior dorsal vertebrae and may be a remnant that was originally lodged within the gullet of the living animal.

Fig. 10. Stratigraphic table of the Middle Jurassic to Late Cretaceous with distribution of the Pliosauroidea. Data after v. Huene (1934), Tarlo (1960), Welles (1962), Persson (1963), Zhang (1985), Hampe (1992), Bardet et al. (1993, 1994), Bardet (1995), Carpenter (1996), Weems \& Blodgett (1996), Cruickshank (1997), Cruickshank \& Long (1997), Gasparini (1997), Storrs et al. (2000), O'Keefe (2001), Buchy et al. (2003). The taxonomy of Kronosaurus n. sp., aff. K. boyacensis (Gómez 2001) is considered as not resolved yet. The Neocomian "Gap" comprises 15 Ma minimum after recent knowledge. Whether Plesiopleurodon belongs to the Brachaucheniidae remains unclear because the length of the neck (number of cervical vertebrae) is still unknown. Further discussion, see text. 


\section{Acknowledgements}

I thank Jens Dücker, Erfde-Ekel/Schleswig-Holstein, Erik Sick, Cologne, Michael Tauchert, Hamburg, and Camillo Monroy, Bogotá, for their help during the short expedition. I am grateful to Pedro Patarroyo, Bogotá, for collaboration in Villa de Leyva and for scientific exchange. I warmly thank Mary Luz Parra Reguth, Villa de Leyva, and Stephan Schult$\mathrm{ka}$, Berlin, for their assistance at the fossil site. Jan MüllerEdzards, Berlin, provided the geological map (Fig. 1), and Elke Siebert, Berlin redrew illustrations for Fig. 9.

Thank you also to Olivier Rieppel, Chicago, for valuable discussion and to Gloria Arratia, Berlin, for conversation and translation of the "Resumen". David M. Unwin, Berlin, kindly gave comments on the manuscript. I appreciated the communication with María Eurídice Páramo Fonseca, Bogotá

The expedition was supported by "Gruppe 5 Filmproduktion", Cologne, with a generous financial contribution.

I express sincere thanks to Kenneth Carpenter, Denver and Eberhard "Dino" Frey, Karlsruhe, who reviewed the manuscipt and suggested many helpful comments.

\section{References}

Acosta, C. E., Huertas, G. \& Ruiz, P. M. 1979. Noticia preliminar sobre el hallazgo de un presunto Kronosaurus (Reptilia: Dolichorhynchopidae) en el Aptiano superior de Villa de Leiva, Colombia. - Lozania (Acta Zoologica Colombiana) 28: 1-7.

Adams, D. A. 1997. Trinacromerum bonneri, new species. Last and fastest pliosaur of the Western Interior Seaway. - The Texas Journal of Science 49 (3): 179-198.

Andrews, C. W. 1897. On the structure of the skull of a pliosaur. - Quarterly Journal of the Geological Society of London 53: 177-185.

- 1910. Note on a mounted skeleton of a small pliosaur, Peloneustes philarchus, Seeley, sp. - Geological Magazine 7: $110-112$.

- 1913. A descriptive catalogue of the marine reptiles of the Oxford clay. Part 2. 206 pp., Trustees of the British Museum, London.

- 1922. Description of a new plesiosaur from the the weald clay of Berwick (Sussex). - Quarterly Journal of the Geological Society of London 78: 285-298.

Applegate, S. P. 1996. An overview of the Cretaceous fishes of the quarries near Tepexi de Rodríguez, Puebla, México. In Arratia, G. \& Viohl, G. (eds.): Mesozoic fishes - Systematics and Paleoecology: 529-538, Pfeil, Munich.

Bakker, R. T. 1993. Plesiosaur extinction cycles - events that mark the beginning, middle and end of the Cretaceous. In Caldwell, W. G. E. \& Kauffman, E. G. (eds.): Evolution of the Western Interior Basin. - Geological Association of Canada: Special paper 39: 641-664.

Bardet, N. 1994. Extinction events among Mesozoic marine reptiles. - Historical Biology 7 (4): 313-324.

- 1995. Evolution et extinction des reptiles marines au cours du Mésozoque. - Palaeovertebrata 24 (3-4): 177-283.

Bardet, N. \& Godefroit, P. 1998. A preliminary cladistic analysis of the Plesiosauria. - Journal of Vertebrate Paleontology Supplement 18 (3): 26A.

Bardet, N., Mazin, J.-M. \& Martin, M. 1993. Une mandibule de Pliosaurus brachyspondylus (Reptilia, Sauropterygia) dans le Kimméridgien du Boulonnais (France). - Neues Jahrbuch für Geologie und Paläontologie Monatshefte 1993 (7): 385-392.

Bardet, N., Lachkar, G. \& Escuille, F. 1994. Présence à l'Oxfordien de Pliosaurus brachyspondylus (Reptilia, Pliosauridae) déterminée par les données palynologiques. - Revue de Micropaléontologie 37 (3): 181-188. de Blainville, H. D. 1835. Description de quelque espèces de reptiles de la Californie, précédée de l'analyse d'un système général d'Erpétologie et d'Amphibiologie. - Nouvelles Annales du Muséum d'Histoire Naturelle 4: 233-296.

Bonaparte, J. F. 1978. El Mesozoico de America del Sur y sus Tetrapodos. 596 pp., Ministerio de Cultura y Education, Tucumán, Argentina.

Brito, P. M. 1997. Révision des Aspidorhynchidae (Pisces, Actinopterygii) du Mesozoque: ostéologie, relations phylogénetiques, données environnementales et biogéographiques. - Geodiversitas 19 (4): 681-772.

Brown, D. S. 1981. The English Upper Jurassic Plesiosauroidea (Reptilia) and a review of the phylogeny and classification of the Plesiosauria. - Bulletin of the British $\mathrm{Mu}$ seum (Natural History), Geology 35 (4): 253-347.

Buchy, M.-C., Frey, E., Stinnesbeck, W. \& López-Oliva, J. G. 2003. First occurrence of a gigantic pliosaurd plesiosaur in the Late Jurassic (Kimmeridgian) of Mexico. - Bulletin de la Société Géologique de France 174 (3): 271-278.

Carpenter, K. 1996. A review of short-necked plesiosaurs from the Cretaceous of the Western Interior, North America. - Neues Jahrbuch für Geologie und Paläontologie Abhandlungen 201 (2): 259-287.

- 1997. Comparative cranial anatomy of two North American Cretaceous plesiosaurs. In Callaway, J. M. \& Nicholls, E. L. (eds.): Ancient marine reptiles: 191-216, Academic Press, San Diego.

- 1999. Revision of North American elasmosaurs from the Cretaceous of the Western Interior. - Paludicola 2 (2): 148-173.

Cruickshank, A. R. I. 1997. A Lower Cretaceous pliosauroid from South Africa. - Annals of the South African Museum 105 (2): 207-226.

Cruickshank, A. R. I. \& Long, J. A. 1997. A new species of pliosaurid reptile from the Early Cretaceous Birdrong Sandstone of Western Australia. - Records of the Western Australian Museum 18 (3): 263-276.

Druckenmiller, P. S. 1999. Osteology and relationships of a new plesiosaur from the Thermopolis Shale of Montana. - Journal of Vertebrate Paleontology Supplement 19 (3): 42A.

Etayo Serna, F. 1968. El sistema Cretáceo en la región de Villa de Leiva y zonas próximas. - Revista Geología Colombiana 5: 5-74.

Flügel, E. \& Kiessling, W. 2002. Patterns of Phanerozoic reef crises. In Kiessling, W., Flügel, E. \& Golonka, J. (eds.): Phanerozoic ree patterns. - SEPM Special Publication 72: 691-733.

Forero, H. \& Sarmiento, L. 1985. La facies evaporítica de la Formación Paja en la región Villa de Leiva. In Etayo-Serna, F. \& Montaño, F. L. (eds.): Proyeto Cretácico. - Publicaciones geológicas especiales del INGEOMINAS 16 (17): $1-16$.

Fraas, E. 1910. Plesiosaurier aus dem oberen Lias von Holzmaden. - Palaeontographica 57 (3/4): 105-140.

de la Fuente, M. \& Goñi, R. 1983. Primeras tortugas cretácicas marinas de Colombia. - Geología Norandina 7: 43-48.

Gasparini, Z. 1997. A new pliosaur form the Bajocian of the Neuquén Basin, Argentina. - Palaeontology 40 (1): 135-147.

Gómez, M. 2001. Estudio morphológico y taxonómico del cráneo de un reptil marino proveniente de capas de la Formación Paja, Quebrada Pavachoque, Municipio de Sutamarchán. 124 pp., Univ. Nat. Colombia, Bogotá (unpubl. Master's thesis).

Goñi, R. \& Gasparini, Z. 1983. Nuevos restos de "Alzadasaurus colombiensis" (Reptilia, Plesiosauria) del Cretácico temprano de Colombia. - Geología Norandina 7: 49-54.

Hallam, A. \& Wignall, P. B. 1997. Mass extinctions and their aftermath. 320 pp., Univ. Press, Oxford.

Halstead, L. B. 1971. Liopleurodon rossicus (Novozhilov) A pliosaur from the Lower Volgian of the Moscow basin. - Palaeontology 14 (4): 566-570.

Hampe, O. 1992. Ein großwüchsiger Pliosauride (Reptilia: Plesiosauria) aus der Unterkreide (oberes Aptium) von 
Kolumbien. - Courier Forschungsinstitut Senckenberg 145: $1-32$.

Hampe, O. \& Leimkühler, C. 1996. Die Anwendung der Photogrammetrie in der Wirbeltierpaläontologie am Beispiel eines Kronosaurus-Fundes in Kolumbien. - Mainzer geowissenschaftliche Mitteilungen 25: 55-78.

v. Huene, E. 1949. Studie über die Umwandlung des Landfußes in den Schwimmfuß bei Sauropterygiern und Placodontiern, gezeigt an der Vorderextremität. - Neues Jahrbuch für Mineralogie, Geologie und Paläontologie Abhandlungen Abteilung B 90: 96-162.

v. Huene, F. 1934. Ein großer Pliosaurus aus dem schwäbischen Ornatenton. - Jahreshefte des Vereins für Vaterländische Naturkunde in Württemberg 90: 31-46.

Knight, W. C. 1895. A new Jurassic plesiosaur from Wyoming. - Science 2 (40): 449.

Lees, T. \& Bartholomai, A. 1987. Study of a Lower Cretaceous actinopterygian (Class Pisces) Cooyoo australis from Queensland, Australia. - Memoirs of the Queensland Museum 25(1): 177-192.

Linder, H. 1913. Beiträge zur Kenntnis der Plesiosaurier-Gattungen Peloneustes und Pliosaurus. - Geologische und Paläontologische Abhandlungen 11 (5): 339-409.

Longman, H. A. 1924. Some Queensland fossil vertebrates. Memoirs of the Queensland Museum 8 (1): 16-28.

Lydekker, R. 1889. Catalogue of the fossil reptilia and amphibia in the British Museum (Natural History). Part 2 containing the orders Ichthyopterygia and Sauropterygia. 307 pp., Taylor \& Francis, London.

Mann, U., Stöhr, D. \& Patarroyo, P. 1994. Erste Ergebnisse biostratigraphischer und lithostratigraphischer Untersuchungen an kretazischen Schwarzschiefern in Villa de Leiva, Boyacá, Kolumbien. - Giessener Geologische Schriften 51: 149-164.

Martill, D. M., Taylor, M. A. \& Duff, K. L. 1994. The trophic structure of the biota of the Peterborough Member, Oxford Clay Formation (Jurassic), UK. - Journal of the Geological Society London 151: 173-194.

Molnar, R. E. 1991. Fossil reptiles in Australia. In VickersRich, P., Monaghan, J. M., Baird, R. F. \& Rich, T. H. (eds.): Vertebrate palaeontology of Australasia: 605-702, Monash, Melbourne.

Nicholls, E. L. \& Russell, A. P. 1990. Paleobiogeography of the Cretaceous Western Interior Seaway of North America: the vertebrate evidence. - Palaeogeography, Palaeoclimatology, Palaeoecology 79: 149-169.

Novozhilov, N. I. 1948. Dva novych pliozavra iz nidznyego voldzskogo yarusa povoldzya. - Doklady Akademia Nauk SSSR 60 (1): 115-118.

O'Keefe, F. R. 2001. A cladistic analysis and taxonomic revision of the Plesiosauria (Reptilia: Sauropterygia). - Acta Zoologica Fennica 213: 1-63.

- 2002. The evolution of plesiosaur and pliosaur morphotypes in the Plesiosauria (Reptilia: Sauropterygia). - Paleobiology 28 (1): 101-112.

Owen, R. 1860. On the orders of fossil and recent Reptilia, and their distribution in time. - Report of the TwentyNinth Meeting of the British Association for the Advancement of Science, held at Aberdeen in September 1859: 153-166.

Páramo, M. E. 1997. Platypterygius sachicarum (Reptilia, Ichthyosauria) nueva especie del Cretácico de Colombia. - Revista INGEOMINAS 6: 1-12.

Patarroyo, P. 2000. Distribución de Amonitas del Barremiano de la Formación Paja en el Sector de Villa de Leyva (Boyacá, Colombia). Bioestratigrafía. - Geología Colombiana 25: 149-162.

Persson, P. O. 1963. A revision of the classification of the Plesiosauria with a synopsis of the stratigraphical and geographical distribution of the group. - Lunds Universitets Arsskrift Ny Följd 59 (1): 1-60.

Rieppel, O. 1999. Phylogeny and paleobiogeography of Triassic Sauropterygia: problems solved and unresolved. - Pa- laeogeography, Palaeoclimatology, Palaeoecology 153: 115.

Romer, A. S. \& Lewis, A. D. 1959. A mounted skeleton of the giant plesiosaur Kronosaurus. - Breviora Museum of Comparative Zoology 112: 1-15.

Schultze, H.-P. \& Stöhr, D. 1996. Vinctifer (Pisces, Aspidorynchidae) aus der Unterkreide (oberes Aptium) von Kolumbien. - Neues Jahrbuch für Geologie und Paläontologie Abhandlungen 199 (3): 395-415.

Storrs, G. W. 1993. Function and phylogeny in sauropterygian (Diapsida) evolution. - American Journal of Science 293A: 63-90.

Storrs, G. W. \& Taylor, M. A. 1996. Cranial anatomy of a new plesiosaur genus from the lowermost Lias (Rhaetian/ Hettangian) of Street, Somerset, England. - Journal of Vertebrate Paleontology 16 (3): 403-420.

Storrs, G. W., Arkhangel'skii, M. S. \& Efimov, V. M. 2000. Mesozoic marine reptiles of Russia and other former Soviet republics. In Benton, M. J., Shishkin, M. A., Unwin, D. M. \& Kurochkin, E. N. (eds.): The age of dinosaurs in Russia and Mongolia: 187-210, Univ. Press, Cambridge.

Swinton, W. E. 1930. A new plesiosaur from Warwickshire. Natural History Magazine 2: 271-275.

Tarlo, L. B. 1959a. Pliosaurus brachyspondylus (Owen) from the Kimmeridge clay. - Palaeontology 1 (4): 283-291.

- 1959b. Stretosaurus nov. gen., a giant pliosaur from the Kimeridge clay. - Palaeontology 2 (1): 39-55.

- 1960. A review of the Upper Jurassic pliosaurs. - Bulletin of the British Museum (Natural History), Geology 4 (5): 145-189.

Taylor, M. A. 1992. Taxonomy and taphonomy of Rhomaleosaurus zetlandicus (Plesiosauria, Reptila) from the Toarcian (Lower Jurassic) of the Yorkshire coast. - Proceedings of the Yorkshire Geological Society 49 (1): 4955.

Taylor, M. A. \& Cruickshank, A. R. I. 1993. Cranial anatomy and functional morphology of Pliosaurus brachyspondylus (Reptilia: Plesiosauria) from the Upper Jurassic of Westbury, Wiltshire. - Philosophical Transactions of the Royal Society of London B 341: 399-418.

Thulborn, T. \& Turner, S. 1993. An elasmosaur bitten by a pliosaur. - Modern Geology 18: 489-501.

Weems, R. E., \& Blodgett, R. B. 1996. The pliosaurid Megalneusaurus: A newly recognized occurrence in the Upper Jurassic Naknek Formation of the Alaska Peninsula. In Moore, T. E. \& Dumoulin, J. A. (eds.): Geologic studies in Alaska by the U.S. Geological Survey, 1994. - U.S. Geological Survey Bulletin 2152: 169-176.

Wegner, T. 1914. Brancasaurus Brancai Wegner, ein Elasmosauride aus dem Wealden Westfalens. - Branca-Festschrift: 235-305, Bornträger, Leipzig.

Welles, S. P. 1943. Elasmosaurid plesiosaurs with description of new material from California and Colorado. - Memoirs of the University of California 13 (3): 125-254.

- 1962. A new species of elasmosaur from the Aptian of Colombia and a review of the Cretaceous plesiosaurs. University of California Publications in Geological Sciences 44 (1): 1-96.

Williston, S. W. 1903. North American plesiosaurs. Part I. Field Columbian Museum Publication 73, Geological Series 2 (1): 1-77.

- 1907. The skull of Brachauchenius, with observations on the relationships of the plesiosaurs. - Proceedings of the United States National Museum 32: 477-489.

- 1925. The osteology of the reptiles. 300 pp., Harvard Univ. Press, Cambridge, MA.

Wyse Jackson, P. N. 2004. Thomas Hawkins, Lord Cole, William Sollas and all: Casts of Lower Jurassic marine reptiles in the Geological Museum, Trinity College, Dublin, Ireland. - The Geological Curator 8 (1): 11-18.

Zhang Yihong 1985. A new plesiosaur from middle Jurassic of Sichuan Basin. - Vertebrata palasiatica 23 (3): 235-240. 